\title{
DIRASAH
}

Volume 2, Number 1, Februari 2019

p-ISSN: 2615-0212 | e-ISSN: 2621-2838

https://ejournal.iaifa.ac.id/index.php/dirasah

\begin{tabular}{|c|c|c|}
\hline Accepted: & Revised: & Published: \\
Desember 2018 & Januari 2019 & Februari 2019 \\
\hline
\end{tabular}

\section{Pengaruh Pendekatan Pembelajaran Saintifik terhadap Kreativitas Belajar Siswa}

\author{
Muhammad Amin \\ Universitas Sunan Giri Surabaya, Indonesia \\ e-mail:m.amin99@gmail.com
}

\begin{abstract}
Lack of creativity in student learning so that grouping students randomly in fifth grade makes students insecure in learning, especially for those who have not mastered some of the scientific approaches in participating in class learning. Therefore, the scientific learning approach is considered to be able to improve creativity in class $V$. This research was conducted in March 2018 with a sample of 21 fifth graders. This type of research is quantitative descriptive research. By using data collection techniques: observation, creativity tests, and documentation. The data obtained were analyzed using the percentage formula and product moment correlation formula. The results of the study say that: (1) the implementation of scientific learning in class $V$ is sufficiently categorized, this is evident from the percentage of 76.6\%. (2) The ability of learning creativity of fifth grade students can be said to be sufficient categories, it is proven that the percentage of students' creativity test reaches $72.6 \%$ and the ability to read individually reaches a percentage of 56-75\%. (3) there is influence and magnitude of the influence of the scientific learning approach on the ability of learning creativity of fifth grade students in MINU Waru II, this is based on the calculation of product moment correlation obtained the value " $r$ " counts 0,638 , and compared with the value " $r$ " product moment for $N=21$ in the $5 \%$ interval, the value " $r$ " is 0.413 and for $1 \%$ interval is 0.526 . Then the " $r$ " value is interpreted. Because the result of " $r$ " count is 0.638 at the point between $0.40-0.70$ which means that in the medium high category. So the influence of the scientific learning approach to the learning creativity of fifth grade students at MINU Waru II, Waru Subdistrict, Sidoarjo Regency has significant significance.
\end{abstract}

Keywords: Scientific Learning, Creativity 


\section{Pendahuluan}

Seiring berjalannya waktu, pendidikan saat ini berpandangan bahwa siswa bukan hanya objek pendidikan, tetapi subjek pendidikan yang di dalamnya terdapat potensi-potensi alami yang siap dikembangkan. Pendidikan membentuk watak dan memberi kesempatan kepada peserta didik untuk dapat mengembangkan potensi yang dimiliki sehingga menghasilkan kecerdasan dan keterampilan yang dapat diaplikasikan dalam kehidupan bermasyarakat. Saat ini, pembelajaran dalam pendidikan di Indonesia masih banyak berpusat pada guru (teacher center). Pada sistem pembelajaran model Teacher Centered Learning, guru lebih banyak melakukan kegiatan belajar-mengajar dengan bentuk ceramah (lecturing). Pada saat mengikuti pembelajaran atau mendengarkan ceramah, siswa sebatas memahami sambil membuat catatan, bagi yang merasa memerlukannya ${ }^{1}$.

Dilihat dari pendekatannya, pembelajaran terdapat dua jenis pendekatan, yaitu: (1) pendekatan pembelajaran yang berorientasi atau berpusat pada siswa (student centered approach) dan (2) pendekatan pembelajaran yang berorientasi atau berpusat pada guru (teacher centered approach). ${ }^{2}$

Salah satu pendekatan yang selama ini dianggap berpusat pada siswa adalah pendekatan saintifik (scientific approach). Permendikbud No. 22 Tahun 2016 tentang Standar Proses Pendidikan Dasar dan Menengah telah mengisyaratkan tentang perlunya proses pembelajaran yang dipandu dengan kaidah-kaidah pendekatan saintifik/ilmiah. Sesuai dengan Standar Kompetensi Lulusan, sasaran pembelajaran mencakup pengembangan ranah sikap, pengetahuan, dan keterampilan yang dielaborasi untuk setiap satuan pendidikan. ${ }^{3}$

Karakteristik kompetensi beserta perbedaan lintasan perolehan turut serta mempengaruhi karakteristik standar proses. Untuk memperkuat pendekatan ilmiah (scientific), tematik terpadu (tematik antar mata pelajaran), dan tematik (dalam suatu mata pelajaran) perlu diterapkan pembelajaran berbasis penyingkapan/penelitian (discovery/inquiry learning). Kemendikbud juga memberikan konsepsi tersendiri bahwa pendekatan ilmiah (scientific approach) dalam pembelajaran di dalamnya mencakup komponen: Mengamati, Menanya,

\footnotetext{
${ }^{1}$ Nana Sudjana, Media Pengajaran (Bandung: Sinar Baru, 2010), 19.

2 Achmad Sudrajat, Pengertian Pendekatan, Strategi, Metode, Teknik Dan Model Pembelajaran (Bandung: Sinar Baru Algensindo, 2008), 3.

${ }^{3}$ Permendikbud No. 22 Tahun 2016 tentang Standar Proses Pendidikan Dasar dan Menengah.
}

Dirasah, Vol. 2, No. 1, Februari 2019 
Mencoba, Menalar, dan Mengkomunikasikan. Pendekatan ilmiah atau scientific aproach pada pelaksanaan pembelajaran menjadi bahan pembahasan yang menarik perhatian para pendidik akhir-akhir ini, terutama setelah diberlakukannya kurikulum 2013. Yang menjadi latar belakang pentingnya materi ini karena produk pendidikan dasar dan menengah belum menghasilkan lulusan yang mampu berpikir kritis setara dengan kemampuan anak-anak bangsa lain. $^{4}$

Kreativitas merupakan suatu tuntutan pendidikan dan kehidupan yang sangat penting pada saat ini. Kreativitas akan menghasilkan berbagai inovasi dan perkembangan baru dalam suatu kehidupan. Potensi kreatif yang sangat penting tersebut pada dasarnya dimiliki oleh setiap anak, bahwa anak-anak memiliki ciriciri oleh para ahli sering digolongkan sebagai ciri individu kreatif, misalnya: rasa ingin tahu yang besar, senang bertanya, imajinasi yang tinggi, berani menghadapi risiko, senang akan hal-hal yang baru, dan lain sebagainya. Kreativitas belajar merupakan salah satu indikator keberhasilan siswa dalam belajar memegang peranan penting dalam pencapaian keberhasilan pembelajaran. Siswa yang memiliki kreativitas dalam pembelajaran akan diketahui dengan menunjukkan tingkat kreativitasnya dalam berbagai kegiatan. Mereka selalu ingin memecahkan masalah atau persoalan-persoalan, berani menanggung risiko yang sulit sekalipun, lebih senang bekerja sendiri atau mandiri, selalu ingin tahu atau memiliki rasa ingin tahu yang tinggi, senang mencari pengalaman yang baru, dan percaya pada diri sendiri. Dengan begitu, dapat dikatakan bahwa pendekatan saintifik diharapkan dapat membuat siswa lebih kreatif. Namun, karena tergolong pendekatan baru di Indonesia, belum ada penelitian yang mengungkap secara empirik bahwa pendekatan saintifik dapat mempengaruhi kreativitas belajar siswa. Hal inilah yang menjadi dasar peneliti untuk mengetahui lebih lanjut mengenai seberapa besar pengaruh pendekatan saintifik terhadap kreativitas belajar siswa. Oleh karena itu, peneliti terdorong untuk mengungkap kebenaran mengenai latar belakang tersebut peneliti dengan mengambil judul "Pengaruh Pendekatan Pembelajaran Saintifik Terhadap Kreativitas Belajar Siswa Kelas V di MINU Waru II Sidoarjo”. Berdasarkan uraian di atas, maka tujuan penelitian ini adalah untuk mengetahui bagaimana pendekatan saintifik dalam pembelajaran siswa, bagaimana kreativitas belajar siswa dan untuk mengetahui

\footnotetext{
${ }^{4}$ Musfiqon Muhammad and Nurdyansyah Nurdyansyah, Pendekatan Pembelajaran Saintifik (Sidoarjo: Nizamia Learning Center, 2015), 55.
} 
adakah pengaruh pendekatan pembelajaran saintifik terhadap kreativitas belajar siswa di MINU Waru II Sidoarjo.

\section{Metode Penelitian}

Penelitian ini dilaksanakan di Madrasah Ibtidaiyah Nahdlatul 'Ulama Waru II Sidoarjo, tepatnya dikelas V. Penelitian ini menggunakan jenis penelitian kuantitatif. Penelitian kuantitatif menurut Sugiyono dapat diartikan sebagai metode penelitian yang digunakan untuk meneliti populasi atau sampel tertentu, teknik pengambilan sampel umumnya dilakukan secara random, pengumpulan datanya menggunakan instrument penelitian, analisis data statistik, serta bertujuan untuk menguji hipotesis yang telah ditetapkan. ${ }^{5}$ Adapun Populasi dalam penelitian ini dijadikan sebagai sampel. Yakni keseluruhan siswa kelas lima. Pengumpulan data dalam penelitian ini menggunakan tes kreativitas untuk mengukur kemampuan kreativitas belajar siswa dan lembar observasi siswa untuk mengukur aspek pendekatan pembelajaran saintifik meliputi, observasi, tes kreativitas, dan dokumentasi.

\section{Kajian Teori}

Pendekatan pembelajaran merupakan jalan yang akan ditempuh oleh guru dan siswa dalam mencapai tujuan instruksional untuk suatu satuan instruksional tertentu. Pendekatan saintifik dimaksudkan untuk memberi pemahaman kepada peserta didik untuk mengetahui, memahami, mempraktikkan apa yang sedang dipelajari secara ilmiah. Oleh karena itu, dalam proses pembelajaran diajarkan agar peserta didik pencari tahu dari berbagai sumber melalui mengamati, menanya, mencoba, mengolah, menyajikan, menyimpulkan, dan mencipta untuk semua mata pelajaran) ${ }^{6}$. Bahwa pendekatan saintifik adalah suatu jalan yang ditempuh guru dan siswa dalam proses pembelajaran dengan memberi pengalaman langsung pada siswa melalui kegiatan observasi, menanya, mengumpulkan informasi, mencoba, menganalisis, menyimpulkan, dan mengkomunikasikan.

Prinsip-prinsip kegiatan pembelajaran dengan pendekatan saintifik kurikulum 2013, yakni :

1. Peserta didik difasilitasi untuk mencari tahu

\footnotetext{
${ }^{5}$ Sugiyono, Metode Penelitian Pendidikan (Bandung: Alfabeta, 2010), 14.

${ }^{6}$ Muhammad and Nurdyansyah, Pendekatan Pembelajaran Saintifik, 48.
}

Dirasah, Vol. 2, No. 1, Februari 2019 
2. Peserta didik belajar dari berbagai sumber belajar

3. Proses pembelajaran menggunakan pendekatan ilmiah

4. Pembelajaran berbasis kompetensi

5. Pembelajaran terpadu

6. Pembelajaran yang menekankan pada jawaban divergen yang memiliki kebenaran multi dimensi

7. Pembelajaran berbasis keterampilan aplikatif

8. Peningkatan keseimbangan, kesinambungan, dan keterkaitan antara hardskills dan soft-skills

9. Pembelajaran yang mengutamakan pembudayaan dan pemberdayaan peserta didik sebagai pembelajar sepanjang hayat

10. Pembelajaran yang menerapkan nilai-nilai dengan memberi keteladanan (Ing Ngarso Sung Tulodo), membangun kemauan (Ing Madyo Mangun Karso), dan mengembangkan kreativitas peserta didik dalam proses pembelajaran (Tut Wuri Handayani)

11. Pembelajaran yang berlangsung di rumah, di sekolah, dan di masyarakat

12. Pemanfaatan teknologi informasi dan komunikasi untuk meningkatkan efisiensi dan efektivitas pembelajaran

13. Pengakuan atas perbedaan individual dan latar belakang budaya peserta didik

14. Suasana belajar menyenangkan dan menantang.

Tujuan pembelajaran dengan pendekatan saintifik didasarkan pada keunggulan pendekatan tersebut. Beberapa tujuan pembelajaran dengan pendekatan saintifik adalah:

1. Untuk meningkatkan kemampuan intelek, khususnya kemampuan berpikir tingkat tinggi siswa.

2. Untuk membentuk kemampuan siswa dalam menyelesaikan suatu masalah secara sistematik.

3. Terciptanya kondisi pembelajaran dimana siswa merasa bahwa belajar itu merupakan suatu kebutuhan.

4. Diperolehnya hasil belajar yang tinggi.

5. Untuk melatih siswa dalam mengomunikasikan ide-ide, khususnya dalam menulis artikel ilmiah.

6. Untuk mengembangkan karakter siswa.

Langkah-langkah pendekatan pembelajaran saintifik yakni proses pembelajaran pada Kurikulum 2013 untuk semua jenjang dilaksanakan 
dengan menggunakan pendekatan ilmiah (saintifik). Langkah-langkah pendekatan ilmiah (scientific appoach) dalam proses pembelajaran meliputi menggali informasi melalui pengamatan, bertanya, percobaan, kemudian mengolah data atau informasi, menyajikan data atau informasi, dilanjutkan dengan menganalisis, menalar, kemudian menyimpulkan, dan mencipta. Untuk mata pelajaran, materi, atau situasi tertentu, sangat mungkin pendekatan ilmiah ini tidak selalu tepat diaplikasikan secara prosedural. Pada kondisi seperti ini, tentu saja proses pembelajaran harus tetap menerapkan nilai-nilai atau sifat-sifat ilmiah dan menghindari nilai-nilai atau sifat-sifat non ilmiah.

Salah satu kemampuan utama yang memegang peranan penting dalam kehidupan dan perkembangan manusia adalah kreativitas. Kemampuan ini banyak dilandasi oleh kemampuan intelektual seperti intelegensi, bakat dan kecakapan hasil belajar, tetapi juga di dukung oleh faktor-faktor afektif dan psikomotor.

Utami Munandar memberikan rumusan tentang kreativitas adalah kemampuan untuk membuat kombinasi baru, berdasarkan data, informasi atau unsur yang ada, menemukan banyak kemungkinan jawaban terhadap suatu masalah. Dimana penekanannya adalah pada kualitas, ketepatgunaan dan keragaman jawaban yang mencerminkan kelancaran dalam berpikir serta kemampuan untuk mengelaborasi suatu gagasan. ${ }^{7}$ Bahwa kreativitas belajar adalah proses pembelajaran dimana siswa difasilitasi untuk mengekspresikan dan mengaktualisasikan diri terkait dengan interaksi diri sendiri, orang lain dan lingkungan yang hasilnya menemukan dan menciptakan sesuatu yang baru. Kreativitas akan menjadi seni ketika seseorang melakukan kegiatan. Dari pemikiran yang sederhana itu, penulis melakukan semua aktivitas yang bertujuan untuk memacu atau menggali kreativitas. Kecerdasan tanpa mental yang sehat sulit sekali dapat menghasilkan karya kreatif. Tujuan mengembangkan kreativitas anak adalah sebagai berikut:

1. Mengenal cara mengekspresikan diri melalui hasil karya dengan menggunakan teknik-teknik yang dikuasainya.

2. Mengenalkan cara dalam menemukan alternatif pemecahan masalah.

3. Membuat anak memiliki sikap keterbukaan terhadap berbagai

4. pengalaman dengan tingkat kelenturan dan toleransi yang sangat tinggi terhadap ketidakpastian.

${ }^{7}$ U Munandar, Pengembangan Kreativitas Anak Berbakat (Jakarta: PT. Rineka Cipta, 1999), 45.

Dirasah, Vol. 2, No. 1, Februari 2019 
5. Membuat anak memiliki kepuasan diri terhadap apa yang dilakukannya dan sikap menghargai hasil karya orang lain.

Adapun fungsi pengembangan kreativitas pada anak sebagai berikut:

1. Fungsi pengembangan kreativitas terhadap perkembangan kognitif anak. Melalui pengembangan kreativitas anak memperoleh kesempatan untuk memenuhi kebutuhan berekspresi menurut caranya sendiri, menciptakan sesuatu yang lain dan baru. Kegiatan yang menghasilkan sesuatu ini dapat memupuk sikap untuk terus sibuk diri dengan kegiatan kreatif akan memacu perkembangan kognitif atau keterampilan berpikir.

2. Fungsi pengembangan kreativitas terhadap kesehatan jiwa. Pengembangan kreativitas mempunyai nilai terapis karena dalam kegiatan berekspresi itu anak dapat menyalurkan perasaan-perasaan yang dapat menyebabkan ketegangan-ketegangan pada dirinya, seperti perasaan lebih, kecewa, khawatir, takut dan lain-lain yang mungkin tidak dapat dikatakannya.

3. Fungsi pengembangan kreativitas terhadap perkembangan estetika. Selain kegiatan berekspresi yang bersifat mencipta anak juga dibiasakan dan dilatih untuk menghayati bermacam-macam keindahan seperti keindahan alam, lukisan tarian, musik dan sebagainya.

Menurut Utami Munandar setiap orang pada dasarnya memiliki bakat kreatif dan kemampuan untuk mengungkapkan dirinya secara kreatif, meskipun masing-masing dalam bidang dan dalam kadar yang berbeda-beda. Yang terutama penting bagi dunia pendidikan ialah bahwa bakat tersebut dapat dan perlu dikembangkan dan ditingkatkan. ${ }^{8}$

Sehubungan dengan pengembangan kreativitas siswa, kita perlu meninjau empat aspek dari kreativitas, yaitu pribadi, pendorong, press, proses, proses, atau, dan produk (4P dari kreativitas). Adapun tabel indikator kreativitas dalam pembelajaran sebagai berikut:

${ }^{8}$ Ibid.

Dirasah, Vol. 2, No. 1, Februari 2019 
Tabel Empat Aspek Kreatifitas

\begin{tabular}{|c|c|c|}
\hline Sub Variabel & Indikator & Dimensi \\
\hline \multirow{4}{*}{$\begin{array}{l}\text { Aspek yang dikembangkan dalam } \\
\text { teori Utami Munandar } 4 \mathrm{P} \text { dalam } \\
\text { pengembangan kreativitas }\end{array}$} & $\begin{array}{l}\text { 1. Pribadi } \\
\text { kreatif }\end{array}$ & $\begin{array}{ll}\text { a. } & \text { Percaya diri } \\
\text { b. Ketekunan }\end{array}$ \\
\hline & $\begin{array}{l}\text { 2. Press } \\
\text { (dorongan) }\end{array}$ & $\begin{array}{ll}\text { a. } & \text { Memberikan } \\
\text { semangat } \\
\text { b. Pantang menyerah }\end{array}$ \\
\hline & 3. Proses kreatif & $\begin{array}{ll}\text { a. } & \text { Persiapan } \\
\text { b. } & \text { Inkubasi } \\
\text { c. } & \text { luminasi } \\
\text { d. } & \text { Verivikasi } \\
\end{array}$ \\
\hline & $\begin{array}{l}\text { 4. Produk } \\
\text { kreatif }\end{array}$ & $\begin{array}{l}\text { a. Pengetahuan } \\
\text { b. Ketrampilan }\end{array}$ \\
\hline
\end{tabular}

Peningkatan kualitas pembelajaran menuntut kemandirian guru untuk menciptakan suasana belajar yang kondusif, agar para peserta didik dapat mengembangkan aktivitas dan kreativitas belajarnya secara optimal, sesuai dengan kemampuannya masing-masing. Dari berbagai pengalaman dan pengamatan terhadap perilaku peserta didik dalam pembelajaran, aktivitas dan kreativitas dapat dikembangkan dengan memberi kepercayaan, komunikasi yang bebas, pengarahan diri, dan pengawasan yang tidak terlalu ketat. Penerapan dapat dilakukan dengan cara berikut:

a. Mengembangkan keberanian dan rasa percaya diri peserta didik, serta mengurangi perasaan-perasaan yang kurang menyenangkan.

b. Memberi kesempatan kepada seluruh peserta didik untuk berkomunikasi secara aktif dan terarah.

c. Melibatkan peserta didik dalam menentukan tujuan belajar dan penilaian hasilnya.

d. Memberikan pengawasan yang tidak terlalu ketat dan tidak otoriter.

e. Melibatkan mereka secara aktif, kreatif, efektif, dan menyenangkan dalam proses pembelajaran secara keseluruhan.

Apa yang dikemukakan di atas tidak terlalu sulit untuk dilakukan dalam pembelajaran, guru dapat melakukannya antara lain dengan mengembangkan modul pembelajaran yang heuristik dan hipotetik. Melalui modul, peran guru dalam pembelajaran bisa dikurangi karena mereka lebih memposisikan dirinya sebagai fasilitator dan mengembangkan modul-modul pembelajaran yang efektif 
dan menyenangkan. Dapat dikemukakan bahwa aktivitas dan kreativitas peserta didik dalam belajar sangat bergantung pada aktifitas dan kreativitas guru dalam pembelajaran dan menciptakan lingkungan belajar yang kondusif. Untuk kepentingan tersebut, guru dapat mengembangkan program-program pembelajran yang menaraik, seperti modul, dan dapat menggunakan berbagai pendekatan dalam meningkatkan aktifitas dan kreatifitas peserta didik kelas lima di MINU Waru II Sidoarjo.

\section{Hasil Penelitian}

Data yang telah disajikan adalah data yang telah diperoleh dari lembar observasi yang telah disebarkan kepada responden. Lembar observasi ini digunakan untuk mengamati siswa kelas $\mathrm{V}$. Jumlah responden dalam penelitian ini adalah 21 responden. Lembar observasi yang dibuat sebanyak 13 butir soal.

Untuk memperoleh data tentang variabel $\mathrm{X}$ yaitu "Pengaruh pendekatan pembelajaran saintifik" menggunakan metode observasi yang digunakan untuk mengamati 21 responden yakni kelas V MINU II Sidoarjo sebagai sampel pada penelitian ini.

Instrumen soal lembar observasi pendekatan pembelajaran saintifik sebagai berikut:

Berdasarkan hasil analisis data tentang bagaimana pelaksanaan pendekatan pembelajaran saintifik di kelas V MINU Waru II Sidoarjo, menggunakan rumus dengan persentase banyaknya nilai dari 13 butir soal memperoleh skor 76,6\%. Apabila dikonsultasikan pada tabel standar persentase, maka berada pada interval 56\%-75\% dengan interpretasi demikian dapat mengetahui pengaruh pelaksanaan pendekatan pembelajaran saintifik di kelas tinggi di MINU Waru II Sidoarjo tergolong "cukup".

Untuk memperoleh data tentang variabel Y yaitu "kreativitas belajar siswa" maka peneliti menggunakan metode tes kreativitas yang disebarkan pada 21 responden yakni kelas V MINU Waru II Sidoarjo sebagai sampel pada penelitian ini.

Dalam tes kreativitas ini peneliti menyediakan kertas origami, sedotan plastik, dan gambar lingkaran dan segitiga yang sudah tersedia. Yang digunakan untuk mengukur tingkat kreativitas siswa. Nilai variabel Y tersebut sebanyak 3 aspek dalam penilaian tes kreativitas dan disediakan 4 alternatif jawaban, masing-masing mempunyai bobot yang berbeda-beda. Untuk lebih jelasnya berikut instrumen lembar tes kreativitas siswa. 
Alternatif jawaban dalam penskoran tes kemampuan kreativitas sebagai berikut: Kertas Origami, Sedotan Plastik, dan Gambar lingkaran dan segitiga yang sudah tersedia di kertas sebagai berikut :

Skor 4, ketika siswa memenuhi 3 aspek (kecepatan/tanggap, berbentuk real, imajinasi).

1. Skor 3, ketika siswa memenuhi 2 aspek dari 3 aspek (kecepatan/tanggap, berbentuk real, imajinasi). Skor 2, ketika siswa memenuhi 1 aspek dari 3 aspek (kecepatan/tanggap, berbentuk real, imajinasi).

2. Skor 1, ketika siswa tidak memenuhi dari 3 aspek (kecepatan/tanggap, berbentuk real, imajinasi).

Berdasarkan hasil analisis data tentang kemampuan membaca siswa di kelas satu MINU Waru II Sidoarjo, menggunakan rumus dengan persentase seluruh hasil tes kreativitas yang diperoleh dari 3 aspek yang diperhatikan peneliti dalam tes kreativitas dengan masing-masing aspek mempunyai nilai 4 . Adapun perhitungannya sebagai berikut:

$$
\begin{aligned}
& P=\frac{F}{N} \times 100 \% \\
& P=\frac{183}{252} \times 100 \%=72,6 \%
\end{aligned}
$$

Jadi, dari hasil perhitungan di atas dengan skor 72,6\%. Apabila dikonsultasikan pada tabel standar persentase, maka berada pada interval 56\%-75\% dengan interpretasi demikian dapat mengetahui pengaruh pendekatan pembelajaran saintifik terhadap kreativitas belajar siswa di MINU Waru II Sidoarjo tergolong "Cukup". Hasil analisis data berdasarkan koefisien Korelasi Product-Moment dari perhitungan di atas telah diperoleh nilai rxy sebesar 0,638 selanjutnya, nilai rxy $=0,638$ dikonsultasikan pada tabel nilai koofisien korelasi product moment $\mathrm{N}=21$ maka $\mathrm{r}$ tabel pada taraf signifikan $5 \%: \mathrm{rt}=0,413$ sedangkan pada taraf signifikan 1\%: rt =0,526. (Anas Sudjiono, 2012:402). Dari hasil konsultasi tersebut dapat diketahui rxy lebih besar dari $\mathrm{r}$ tabel, baik pada taraf signifikan 5\% maupun pada tarif signifikan $1 \%$ yakni $0,413<0,638>0,526$. Kemudian, untuk mengetahui sejauh mana pengaruh pembelajaran pendekatan saintifik terhadap kreativitas belajar siswa di MINU Waru II Sidoarjo dengan hasil rxy=0,638 dikonsultasikan pada tabel interpretasi di atas, maka $\mathrm{rxy}=0,638$ berada di antara $0,40-0,70$ yang berarti "sedang". 
Selanjutnya, untuk menganalisis hasil perhitungan pengaruh pendekatan pembelajaran saintifik terhadap kreativitas belajar siswa kelas V MINU Waru II Sidoarjo, maka menggunakan rumus produk moment.

Berdasarkan hasil analisis dapat disimpulkan bahwa adanya pengaruh pendekatan pembelajaran saintifik terhadap kreativitas belajar siswa kelas $\mathrm{V}$ di MINU Waru II Sidoarjo dengan tingkat pengaruh yang “sedang". Hal ini sesuai dengan Permendikbud tahun 2013 yang menyatakan pendekatan pembelajaran yang digunakan dalam proses pembelajaran dapat menentukan hasil pembelajaran. Sehingga dapat disimpulkan bahwa pendekatan pembelajaran saintifik dapat mengatasi kreativitas belajar siswa yang dikarenakan pendekatan pembelajaran saintifik memiliki keunggulan yakni dikembangkan berdasarkan kebutuhan siswa, dan mengembangkan proses pembelajaran yang memotivasi, menarik dan menyenangkan.

Sebagaimana yang telah kita ketahui menurut Utami Munandar mengatakan di dalam buku nya Nana Syaodih Sukmadinata alasan mengapa kreativitas penting untuk dimunculkan, dipupuk dan dikembangkan dalam diri anak, antara lain dengan kreativitas memungkinkan manusia meningkatkan kualitas hidupnya. ${ }^{9}$ Gagasan-gagasan baru sebagai buah pemikiran kreatif akan sangat diperlukan untuk menghadapi masa depan yang penuh tantangan. Melalui pendekatan pembelajaran saintifik, maka segala aktivitas dan kegiatan belajar mulai dari mengamati gambar, menceritakan gambar, dialog, berpikir kritis, aktif bertanya, aktif mendemonstrasikan dan dapat meningkatkan kemampuan kreativitas belajar siswa kelas V di MINU Waru II Sidoarjo.

\section{Penutup}

Berdasarkan analisis terhadap data penelitian, maka penulis dapat mengambil beberapa kesimpulan sebagai berikut:

1. Bahwa penerapan pendekatan pembelajaran saintifik di kelas V MINU Waru II Kecamatan Waru Kabupaten Sidoarjo dikatagorikan baik. Hal ini dapat dibuktikan dari hasil responden siswa yang banyak menyatakan bahwa siswa banyak terlibat aktif, memberikan respon, percaya diri, dan mampu mengikuti kegiatan pembelajaran tematik dengan katagori "cukup" dengan hasil persentase $76,6 \%$.

${ }^{9}$ Ibid, 60.

Dirasah, Vol. 2, No. 1, Februari 2019 
2. Kreativitas Belajar Siswa kelas V MINU Waru II Sidoarjo sudah termasuk dalam kategori "cukup". Hal ini diketahui dari hasil tes kreativitas siswa dengan hasil persentase $72,6 \%$.

3. Ada pengaruh pendekatan pembelajaran saintifik terhadap kreativitas belajar siswa kelas V di MINU Waru II Kecamatan Waru Kabupaten Sidoarjo. Hal ini dibuktikan dengan analisis yang dilakukan dengan menggunakan tabel interprestasi. Nilai " $r$ " product moment dengan interval kepercayaan 5\% sebesar 0,413 dan interval $1 \%$ sebesar 0,526 . Jika hasil nilai " $\mathrm{r}$ " $=0,638$ dikonsultasikan pada tabel interprestasi berada diantara 0,40-0,70 dengan katagori "sedang".

\section{Daftar Pustaka}

Kemdikbud. Lampiran Permendikbud No. 21 Tahun 2016, Pub. L. No. 12, Kemdikbud (2016).

Muhammad, Musfiqon, and Nurdyansyah Nurdyansyah. Pendekatan Pembelajaran Saintifik. Sidoarjo: Nizamia Learning Center, 2015.

Munandar, U. Pengembangan Kreativitas Anak Berbakat. Jakarta: PT. Rineka Cipta, 1999.

Sudjana, Nana. Media Pengajaran. Bandung: Sinar Baru, 2010.

Sudrajat, Achmad. Pengertian Pendekatan, Strategi, Metode, Teknik Dan Model Pembelajaran. Bandung: Sinar Baru Algensindo, 2008.

Sugiyono. Metode Penelitian Pendidikan. Bandung: Alfabeta, 2010.

Copyright (C) 2019 Journal Dirasah: Vol. 2, No. 1, Februari 2019, p-ISSN: 2615-0212, e-ISSN; 2621-2838

Copyright rests with the authors

Copyright of Jurnal Dirasah is the property of Jurnal Dirasah and its content may not be copied or emailed to multiple sites or posted to a listserv without the copyright holder's express written permission. However, users may print, download, or email articles for individual use.

https://ejournal.iaifa.ac.id/index.php/dirasah

Dirasah, Vol. 2, No. 1, Februari 2019 